Мальчик М. В., д.е.н., професор, Гонтаренко Н. А., к.е.н., доцент, Хоменчук Д. В., аспірант (Національний університет водного господарства та природокористування, м. Рівне)

\title{
ПОВЕДІНКА КЛІЕНТІВ В УМОВАХ ІНТЕГРОВАНОГО БАНКІВСЬКОГО МАРКЕТИНГУ
}

Розроблено класифікацію чинників поведінки корпоративних та індивідуальних клієнтів комерційних банків. Обґрунтовано основні положення інтегрованого банківського маркетингу. Запропоновано підходи до впливу на поведінку клієнтів в контексті інтегрованого маркетингу.

Ключові слова: комерційний банк, індивідуальний клієнт, корпоративний клієнт, зовнішні та внутрішні чинники поведінки корпоративних клієнтів, зовнішні та внутрішні чинники поведінки індивідуальних клієнтів, концепція інтегрованого банківського маркетингу, вплив на поведінку клієнтів в умовах інтегрованого банківського маркетингу.

Комерційні банки як надзвичайно важлива складова механізму ринкової економіки є:

1) фінансовими посередниками між суб'єктами ринку, які тимчасово мають вільні кошти, і суб'єктами ринку, які потребують додаткових фінансових ресурсів для фінансування важливих проектів власного розвитку;

2) фінансовими посередниками між суб'єктами ринку, які мають тимчасово вільні кошти, і фінансово стійкими суб'єктами господарювання, у яких через специфіку діяльності утворилися так звані касові розриви;

3) ланками, за допомогою яких надається платна фінансова підтримка суб'єктам господарювання, які $\epsilon$ фінансово стабільними, динамічно розвиваються;

4) ланками, за допомогою яких здійснюється економічна санація, адже, наприклад, кредитні кошти не надаються підприємствам 3 незадовільненим фінансовим становищем;

5) установами, які сприяють розвитку інвестиційних процесів в Україні;

6) установами, які надають клієнтам різноманітні послуги (довірчі, консультаційні тощо);

7) установами, які є орієнтиром для суб'єктів національної економіки щодо розвитку інформаційних систем управління бізнесом тощо.

У складі пасивів комерційних банків переважають залучені й запозичені кошти. Для успішного залучення коштів на депозити комерційний банк потребує міцної, стабільної, потужної клієнтської ба- 
зи. В умовах інтенсивної конкуренції на банківському ринку формування, кількісне та якісне нарощування клієнтської бази є архіважливим завданням кожної банківської установи. Якісна клієнтська база - це, як правило, клієнти, які відповідають наступним вимогам:

1) $€$ фінансово стійкими, мають високі показники ділової активності (для суб'єктів бізнесу) і помірковані позиції щодо запозичень (i для юридичних, і для фізичних осіб);

2) мають високоліквідну заставу або інші надійні форми забезпечення кредитних коштів;

3) характеризуються прихильністю до даної банківської установи й середньостроковими або довгостроковими партнерськими відносинами з банком;

4) є привабливими для банківської установи з огляду на її стратегічні завдання.

Клієнти комерційних банків поділяються на індустріальних (юридичні особи, фізичні особи-підприємці) та індивідуальних (громадяни).

Поведінка індустріальних клієнтів $€$ більш передбачуваною у порівнянні з індивідуальними клієнтами, оскільки:

по-перше, прийняття рішень корпоративним клієнтами здійснюється або колегіально, або з врахуванням думок інших фахівців даного підприємства;

по-друге, кредитна, депозитна та інші політики індустріальних клієнтів базуються на єдиній маркетинговій конкурентній стратегії, на певній корпоративній культурі й корпоративних регламентах.

Додаткові фактори передбачуваності корпоративних клієнтів:

1) їх фінансова звітність оприлюднюється на спеціальних вебсайтах (у випадку публічних акціонерних товариств);

2) якщо клієнт має з банком угоду на розрахунково-касове обслуговування, то банківська установа одержує можливість безпосередньо аналізувати рух грошових коштів на поточному рахунку клієнта, що $є$ джерелом достовірної інформації про фінансове становище й можливі потреби клієнта у банківських послугах.

Поведінка індивідуальних клієнтів є результатом дії складного комплексу чинників, які, у порівнянні з корпоративними клієнтами, заздалегідь передбачити більш складно. Крім того, обслуговування індивідуальних клієнтів є більш трудомістким у порівнянні з клієнтами індустріальними (корпоративними). За таких обставин банківська установа самостійно визначає свою клієнтську політику в частині співвідношення своїх корпоративних та індивідуальних клієнтів, особливо коли йде мова про кредитування.

Поведінка клієнтів банківської установи, як корпоративних, так і індивідуальних, залежить від комплексу взаємопов'язаних зовнішніх і внутрішніх чинників. Склад зовнішніх і внутрішніх чинників поведінки корпоративних та індивідуальних клієнтів представлено в 
таблиці.

Склад зовнішніх і внутрішніх чинників поведінки корпоративних та індивідуальних клієнтів комерційного банку

\begin{tabular}{|l|l|l|}
\hline & Корпоративні клієнти банку & Індивідуальні кліє- \\
нти банку
\end{tabular}


Зовнішні чинники поведінки клієнтів - це нерегульовані або дуже слабо регульовані чинники, які банки можуть лише враховувати у своїй діяльності. Для корпоративних клієнтів зовнішні чинники це комплекс чинників макросередовища: загальні макроекономічні, соціально-культурні, політико-правові, природно-географічні, технологічні, демографічні та специфічні макроекономічні чинники. Специфічними макроекономічними чинниками поведінки клієнтів у банківській сфері є: вірогідність панічних настроїв на фінансових ринках, низький рівень доходів населення, дорогі кредитні ресурси, високі ризики для вкладників на українському банківському ринку. Чинником поведінки клієнтів-вкладників банківської установи (як індивідуальних, так і корпоративних) $є$ паніка на фінансових ринках. Головними причинами такої паніки $\epsilon$ погана макроекономічна кон'юнктура, рецесія, прорахунки в державному регулюванні економіки, чутки, недостатньо професійна поведінка контактного персоналу, затримки у виплатах клієнтам тощо. Принцип «гроші люблять тишу» $є$ одним з головних у банківській діяльності.

Специфічним чинником поведінки клієнтів комерційних банків в Україні $є$ низький, у порівнянні з європейськими країнами, рівень доходів населення, його недостатня фінансова культура й малий запас фінансової стійкості багатьох суб'єктів національної економіки. Низький рівень доходів породжує недостатню схильність до заощадження і в багатьох випадках - до безвідповідального відношення до запозичень. Це зменшує коло клієнтів-вкладників і викликає необхідність строго контролювати кредитні банківські ризики.

Важливою групою зовнішніх чинників, які впливають на поведінку клієнтів банківської установи, є спонукальні чинники банківського маркетингу. Вони є інструментами активного банківського маркетингу, коли не просто вивчають потреби й чинники поведінки клі$є н т і в$, але й активно впливають на них задля досягнення цілей бізнесу. Спонукальні чинники маркетингу, на наш погляд, доцільно класифікувати за ознакою складових комплексу маркетингу (базова модель «4Р» або більш деталізовані моделі «7Р», «9Р», які притаманні для сфери послуг, в тому числі і для банківської сфери).

Банківські установи оновлюють власну концепцію маркетингу 3 врахуванням змін у маркетинговому середовищі, наукових досягнень, тенденцій розвитку потреб клієнтів, змін у життєвій філософії та системі цінностей окремих людей і суспільства в цілому.

Одним з напрямів оновлення концепцій маркетингу й підходів до формування та реалізації комплексу маркетингу в банку є інтегрований маркетинг. Ідея інтегрованого маркетингу закладена в самій концепції «4Р», але теоретико-методологічні й практичні засади 
реалізації цієї ідеї досліджені, на наш погляд, недостатньо.

Інтегрований маркетинг в банківській установі, як і на виробничому підприємстві, має, на наш погляд, наступні головні риси [2]:

1) Комплексне, інтегроване застосування концепцій маркетингу (удосконалення виробництва, удосконалення товару, інтенсифікації комерційних зусиль, концепцій маркетингу й соціальноетичного маркетингу, а також концепції взаємодії). 3 класичного переліку вимогам сучасного ринку відповідає концепція взаємодії (партнерського маркетингу). Вважаємо, що концепція вищого рівня не перекреслює, а просто знімає актуальність і ступінь поширення попередніх концепцій, дещо трансформує їх. Концепції нижчого рівня стають інструментами концепції вищого рівня. Вважаємо, що інтегрований маркетинг - це, в тому числі, інтегрування всіх відомих концепцій маркетингу під егідою концепції найвищого на даний момент рівня; при цьому інструменти нижчих за рівнем концепцій доцільно використовувати вибірково, в залежності від ринкової ситуації та маркетингової стратегії.

2) Використання організаційних структур управління маркетингом, які націлені не на процес, а на високу результативність маркетингової діяльності та їі контроль (товарно-функціональна, товарноринкова, матрична структура тощо) [2]. Наприклад, функціональна структура не дає можливості оперативно з'ясовувати та усувати причини недостатньої ефективності комплексу маркетингу банку.

3) Функціонування комплексу банківського маркетингу за моделлю активного маркетингу. Ця модель полягає у поєднанні вивчення, аналізу, прогнозування потреб клієнтів банку з активним впливом на формування вказаних потреб, зі впливом на поведінку клієнтів.

4) Паралельне здійснення двох процесів: створення нових продуктів і позиціонування їх корисності у свідомості клієнтів. Причому клієнт має оцінити такі види корисності, про існування яких він навіть не здогадувався. «В цьому суть концепції інтегрованого маркетингу. ... Маркетинг, по суті, вже розглядається не як один 3 елементів управління, а як глобальна функція, що визначає зміст ... діяльності.... Маркетингова служба бере на себе виконання великої кількості функцій або виступає як консультативний орган щодо інших підрозділів» [2].

5) Комплексне, системне використання всіх інструментів банківського маркетингу; інформаційно-аналітичне обґрунтування потрібного в конкретній ринковій ситуації набору інструментів; ефективне поєднання інструментів он-лайн і оф-лайн маркетингу. Актуальними інструментами он-лайн маркетингу є: веб-сайт, промо-сайт, інтернет-реклама, засоби електронної торгівлі тощо [3]. 
6) Інтегроване (комплексне, системне) врахування всіх чинників і мотивів поведінки клієнтів комерційного банку. Моніторинг поведінки клієнтів з метою виявлення тенденцій поведінки клієнтів і особливостей поведінки найбільш привабливих з них.

7) Комплексне врахування інтересів, потреб, цілей банківської установи та їі клієнтів. Гармонізація в цій сфері $€$ дуже важливою, оскільки сприяє виникненню партнерських відносин з клієнтами. Важливим завданням контактного персоналу банку $є$ з'ясовувати, уточнювати потреби клієнтів та оцінювати можливості їх задоволення з врахуванням стратегічних і тактичних завдань банківської установи.

Чинники поведінки клієнтів можна поділити на раціональні, емоційні та моральні у відповідності до загальноприйнятої класифікації мотивів поведінки споживачів. До раціональних мотивів відноситься бажання клієнтів одержати доходи від банківських послуг, покращити власний імідж задля досягнення комерційних цілей. Емоційні чинники поведінки - це чинники, які ґрунтуються на почуттях, емоціях, сентиментальності, прагненні до любові й самоактуалізації, що притаманні для індивідуальних клієнтів. Тому при безпосередньому спілкуванні з індивідуальними клієнтами дуже важливими $€$ щирість і доброзичливість, визнання унікальності кожної людини, важливості їі життя й цінності всіх ї̈ ресурсів. Особливо шкідливою для банківської установи є ситуація, коли у клієнта в процесі обслуговування створюється відчуття власної другорядності. В поведінці індустріальних клієнтів емоційні чинники не відіграють важливої ролі, оскільки діяльність індустріального клієнта визначається корпоративними регламентами: стандартами, положеннями, наказами, розпорядженнями, посадовими інструкціями тощо. Але в процесі переговорів з представниками корпоративних клієнтів можливий певний емоційний вплив на них з боку банківських працівників.

Моральні чинники поведінки корпоративних клієнтів і самого комерційного банку можуть мати, на наш погляд, такі основні аспекти:

1) прагнення до порядного бізнесу;

2) реалізація концепції соціально-етичного маркетингу (виробництво екологічно чистої продукції, сприяння захисту навколишнього середовища і здоровому способу життя людей, захист флори й фауни тощо).

Важливим елементом порядності банківського бізнесу є надання клієнту повної інформації про параметри банківських продуктів і послуг, навіть коли це дещо невигідно для банківської установи. При 
належним чином організованій роботі з клієнтами це збільшує рівень прихильності клієнтів (тобто кількість бажаючих купувати банківські послуги повторно й надалі) на основі довіри й впевненості у надійності банку.

Моральні чинники поведінки індивідуальних клієнтів полягають у дотриманні певних морально-етичних норм поведінки й висування певних вимог до рівня порядності банківського бізнесу.

Спонукальні чинники маркетингу - це чинники, які впливають на поведінку клієнтів комерційного банку і сприяють нарощуванню обсягів продажів банківських продуктів й послуг, а також збільшенню частки ринку, яку контролює конкретний банк.

Спонукальні чинники банківського маркетингу $є$ актуальними і в роботі з індивідуальними, і в роботі з індустріальними клієнтами. Механізм їх дії має специфіку для кожної з цих двох груп клієнтів. Класифікувати їх вважаємо за доцільне наступним чином.

1. Спонукальні чинники банківського маркетингу в сфері продуктової політики:

1.1. Для юридичних осіб (он-лайн, оф-лайн).

1.2. Для фізичних осіб (он-лайн, оф-лайн).

2. Спонукальні чинники банківського маркетингу у сфері цінової політики:

2.1. Для юридичних осіб (он-лайн, оф-лайн).

2.2. Для фізичних осіб (он-лайн, оф-лайн).

3. Спонукальні чинники банківського маркетингу у сфері політики продажу банківських продуктів:

3.1. Для юридичних осіб (он-лайн, оф-лайн).

3.2. Для фізичних осіб (он-лайн, оф-лайн).

4. Спонукальні чинники банківського маркетингу у сфері політики просування банківських продуктів і послуг (так званих комунікацій банківських продуктів):

4.1. Для юридичних осіб (он-лайн, оф-лайн).

4.2. Для фізичних осіб (он-лайн, оф-лайн).

Кожна банківська установа виходячи з місії та маркетингової стратегії має розробляти детальний перелік чинників маркетингу, оцінювати рівень використання банком та його конкурентами можливостей кожного чинника.

Контактний банківський персонал в процесі оф-лайн взаємодії 3 клієнтами має можливість одержувати зворотну інформацію про ефективність банківського впливу на чинники поведінки клієнтів.

В режимі «он-лайн» (інтернет-банкінг, мобільний банкінг, соціальні мережі) комерційний банк має можливості одержувати важливу додаткову інформацію про поведінку клієнта. Наприклад, При- 
ватбанк у системі «Приват-24» аналізує поведінку клієнтів і вивчає мотиви цієї поведінки [4].

Висновки. В умовах недостатнього рівня доходів домашніх господарств і суб'єктів національної економіки, а також недостатнього рівня довіри до вітчизняної банківської системи суттєво загострюється боротьба у сфері залучення банками клієнтів. Традиційним для банків є гнучкий вибір та оновлення банківських стратегій. Але жорстка конкуренція у банківському секторі економіки робить актуальним удосконалення самої концепції банківського маркетингу. Вважаємо за доцільне для комерційних банків України впроваджувати й удосконалювати концепцію інтегрованого банківського маркетингу. Це буде сприяти підвищенню соціально-економічної ефективності комплексів маркетингу банківських установ, в тому числі завдяки покращанню впливу на поведінку клієнтів.

Концепція інтегрованого банківського маркетингу вимагає систематизації всіх чинників впливу на поведінку клієнтів банківської установи, моніторингу та оцінки їх дії, прийняття та реалізації відповідних маркетингових рішень в режимі реального часу (оперативного маркетингу).

1. Окландер М. А., Жарська І. О. Поведінка споживача : навч. посібник. К. : «Центр учбової літератури», 2014. 208 с. 2. Мальчик М. В., Хоменчук Д. В. Застосування концепції інтегрованого маркетингу на виробничому підприємстві. Маркетинг в умовах розвитку цифрових технологій : матеріали всеукр. наук.-практ. інтернет-конф. (5 жовтня 2018 р). Луцьк : IBB Луцького НTУ, 2018. C. 277-279.

URL: http://elartu.tntu.edu.ua/bitstream/lib/25999/1/збірник матеріалів Маркетинг в умовах розвитку цифрових технологій.pdf (дата звернення: 15.01.2019). 3. Гонтаренко Н. А. Інструменти інтерактивного банківського маркетингу. Вісник НУВГП. Економічні науки : зб. наук. праць. Вип. 1(65). Рівне, 2014. C. 84-91. URL: http://ep3.nuwm.edu.ua/1501/1/Ve659.pdf. (дата звернення: 15.01.2019). 4. Гонтаренко Н. А. Аналіз застосування інтерактивного маркетингу в Приватбанку. Вісник НУВГП. Економічні науки : зб. наук. праць. Рівне : НУВГП, 2017. Вип. 4(80). С. 275-282. URL: http://ep3.nuwm.edu.ua/12426/1/Ve8026\%20\%D0\%B7\%D0\%B0\%D1\%85.pdf (дата звернення: 15.01.2019).

\section{REFERENCES:}

1. Oklander M. A., Zharska I. O. Povedinka spozhyvacha : navch. posibnyk. K. : «Tsentr uchbovoi literatury», 2014. 208 s. 2. Malchyk M. V., Khomenchuk D. V. Zastosuvannia kontseptsii intehrovanoho marketynhu na vyrobnychomu pidpryiemstvi. Marketynh $v$ umovakh rozvytku tsyfrovykh tekhnolohii : materialy vseukr. nauk.-prakt. internet-konf. (5 zhovtnia 2018 r). Lutsk : IVV Lutskoho 
NTU, 2018.2 S. 277-279. URL:

http://elartu.tntu.edu.ua/bitstream/lib/25999/1/zbirnyk materialiv Marketynh $v$ umovakh rozvytku tsyfrovykh tekhnolohii.pdf (data zvernennia: 15.01.2019). 3. Hontarenko N. A. Instrumenty interaktyvnoho bankivskoho marketynhu. Visnyk NUVHP. Ekonomichni nauky : zb. nauk. prats. Vyp. 1(65). Rivne, 2014. S. 84-91. URL: http://ep3.nuwm.edu.ua/1501/1/Ve659.pdf. (data zvernennia: 15.01.2019). 4. Hontarenko N. A. Analiz zastosuvannia interaktyvnoho marketynhu v Pryvatbanku. Visnyk NUVHP. Ekonomichni nauky : zb. nauk. prats. Rivne : NUVHP, 2017. Vyp. 4(80). S. 275-282. URL: http://ep3.nuwm.edu.ua/12426/1/Ve8026\%20\%D0\%B7\%D0\%B0\%D1\%85.pdf (data zvernennia: 15.01.2019).

Рецензент: д.е.н., професор Безтелесна Л. І. (НУВГП)

Malchyk M. V., Doctor of Economics, Professor, Hontarenko N. A., Candidate of Economics (Ph.D.), Associate Professor, Khomenchuk D. V., Post-graduate Student (National University of Water and Environmental Engineering, Rivne)

\section{BEHAVIOR OF CLIENTS UNDER CONDITIONS OF INTEGRATED BANK MARKETING}

Clients of commercial banks are divided into industrial (corporate) clients (legal persons and individual entrepreneurs) and individual clients (citizens). Behavior of industrial clients is based on a common marketing competitive strategy, certain corporate culture and corporate guidelines, rules and regulations. Because of this, behavior of industrial clients is more predictable when compared to individual clients. Behavior of clients of the bank, both corporate and individual, depends on a number of interconnected factors. The developed classification of factors which affect the behavior of clients of banks is as follows: external factors of behavior of corporate clients, external factors of behavior of individual clients, internal factors of behavior of corporate clients, internal factors of behavior of individual clients. Motivational factors of the marketing can be described as factors which influence the behavior of clients of the commercial bank and help to increase the sales of banking products and services, as well as increase the market share which is controlled by a particular bank. We propose the following classification of such factors: motivational factors in the area of product policy, in the area of pricing policy, in the area of banking product sales policy and in the area of promotion policies. One of the directions for updating marketing concepts is 
integrated marketing. Its main provisions are: the use of organizational marketing management structures, which are not aimed at the process of marketing, but at ensuring the high effectiveness of marketing activities and their effective control; functioning of the complex of bank marketing in accordance with the model of active marketing; integrated, systematic use of all tools of bank marketing; integrated (complex, systemic) taking into account of all factors which influence behavior of clients of commercial bank. The concept of integrated bank marketing requires the bank to systematize all factors affecting the behavior of clients of the banking institution, monitor and evaluate its actions, adopt and implement relevant marketing decisions in real time.

Keywords: commercial bank, individual client, corporate client, external and internal factors of behavior of corporate clients, external and internal factors of behavior of individual clients, concept of integrated banking marketing, influencing the behavior of clients in the conditions of integrated banking marketing.

Мальчик М. В., Д.э.н., профессор, Гонтаренко Н. А., к.э.н., доцент, Хоменчук Д. В., аспирант (Национальный университет водного хозяйства и природопользования, г. Ровно)

\section{ПОВЕДЕНИЕ КЛИЕНТОВ В УСЛОВИЯХ ИНТЕГРИРОВАННОГО БАНКОВСКОГО МАРКЕТИНГА}

Разработана классификация факторов поведения корпоративных и индивидуальных клиентов коммерческих банков. Разработаны основные положения интегрированного банковского маркетинга. Предложены подходы к воздействию на поведение клиентов в контексте интегрированного маркетинга.

Ключевые слова: коммерческий банк, индивидуальный клиент, корпоративный клиент, внешние и внутренние факторы поведения корпоративных клиентов, внешние и внутренние факторы поведения индивидуальных клиентов, концепция интегрированного банковского маркетинга, влияние на поведение клиентов в условиях интегрированного банковского маркетинга. 